\title{
NOTA/NOTE
}

\section{Aproximación a la dieta de Thalassoma lucasanum (familia Labridae) en el arrecife coralino de La Azufrada, isla Gorgona, Pacífico Oriental Tropical}

\section{Approximation to the diet of Thalassoma lucasanum (family Labridae) in the coral reef of La Azufrada, Gorgona Island, Eastern Tropical Pacific}

\author{
Stephania Palacios-Narváez ${ }^{1 *}$, Bellineth Valencia ${ }^{l}$ y Alan Giraldo ${ }^{1,2}$ \\ $\begin{array}{lll}\text { (iD) } 0000-0002-8225-4041 & \text { (D) } 0000-0002-1471-8270 & \text { (iD) } 0000-0001-9182-888 X\end{array}$
}

1.Departamento de Biología,Universidad del Valle,Cali,Colombia.stephania.palacios@correounivalle.edu.co,bellineth.valencia@correounivalle.edu.co

2. Instituto de Investigaciones en Ciencias del Mar y Limnología (Incimar), Universidad del Valle, Cali, Colombia.alan.giraldo@correounivalle.edu.co

* Autora de correspondencia

\section{RESUMEN}

$\mathrm{E}$ 1 arcoíris de Cortés, Thalassoma lucasanum, es un pez arrecifal abundante en el Pacífico Oriental Tropical (POT). A diferencia de otras especies del género Thalassoma que son reconocidas por ser limpiadoras, en T. lucasanum este comportamiento es poco frecuente, ya que se alimenta principalmente de invertebrados mediante forrajeo. No obstante, la información sobre la ecología trófica de esta especie es limitada, especialmente en el POT. En este estudio se caracterizan los hábitos alimentarios de T. lucasanum en la isla Gorgona (POT) a partir del análisis de su contenido estomacal y se calcula su nicho trófico. Los moluscos fueron el principal recurso alimentario de T. lucasanum, siendo este el ítem de presa más importante y frecuente al ser encontrado en $100 \%$ de los estómagos analizados $(\mathrm{n}=5)$. En términos de biomasa, los crustáceos presentaron la mayor contribución a la dieta, con lo cual se posicionaron como el segundo ítem alimentario más importante. Otras presas incluyeron poliquetos, partes de peces y material calcáreo. Este estudio contribuye al conocimiento de la dinámica trófica de los ecosistemas arrecifales del POT.

PALABRAS CLAVE: peces de arrecifes coralinos, contenido estomacal, interacciones tróficas, Pacífico colombiano

\section{ABSTRACT}

$\mathrm{T}$ he Cortez rainbow wrasse, Thalassoma lucasanum, is an abundant reef fish of the Eastern Tropical Pacific (ETP). Unlike other species of the genus Thalassoma that are recognized as cleaners, in T. lucasanum this behavior is rare, since it feeds mainly on invertebrates through foraging. However, information on the trophic ecology of this species is limited, especially in the ETP. In this study, we characterize the feeding habits of T. lucasanum in Gorgona Island (ETP) from analyzing its gut contents and calculating its trophic niche. Mollusks were the main food resource of T. lucasanum, being this the most important and frequent prey item found in $100 \%$ of the stomachs analyzed $(n=5)$. In terms of biomass, crustaceans had the greatest contribution to the diet, which positioned them as the second most important food item. Other prey items included polychaetes, fish parts, and calcareous material. This study contributes to the knowledge of the trophic dynamics of coral reef ecosystems of the ETP

KEY WORDS: coral reef fish, stomach content, trophic interactions, Colombian Pacific

DOI: https://doi.org/10.25268/bimc.invemar.2020.49.SuplEsp.1041 
Las especies del género Thalassoma son conocidas por su versatilidad trófica y amplia preferencia dietaria, así como por presentar un comportamiento de forrajeo generalizado en un amplio espectro de microhábitats arrecifales (Fulton et al., 2017; Dunkley et al., 2018). Aunque varias especies de este género son reconocidas por su comportamiento alimentario de limpieza (Arnal et al., 2006; Baliga y Mehta, 2014; Quimbayo et al., 2017), dicho comportamiento se presenta con menor frecuencia en $T$. lucasamun en el Pacífico Oriental Tropical (POT), región donde se alimenta mediante forrajeo principalmente de invertebrados (Quimbayo et al., 2017). La mayoría de la información disponible para esta especie se centra en sus patrones de reproducción, abundancia y distribución (Warner, 1982; Giraldo et al., 2001), pero poco se sabe sobre sus hábitos de alimentación (Foster, 1987; Robertson y Allen, 2015; Quimbayo et al., 2017). Con el propósito de contribuir al conocimiento sobre la ecología trófica de T. lucasanum en el POT, se caracterizó su dieta a partir del análisis del contenido estomacal de especímenes capturados en el arrecife coralino de La Azufrada, isla Gorgona, Pacífico colombiano.

La Azufrada es el arrecife coralino más grande (longitud: $780 \mathrm{~m}$, ancho: $80-180 \mathrm{~m}$ ) y continuo de la isla continental Gorgona $\left(2^{\circ} 58^{\prime} 10^{\prime \prime} \mathrm{N}\right.$ y $\left.78^{\circ} 11^{\prime} 05^{\prime \prime} \mathrm{W}\right)$, localizada a $35 \mathrm{~km}$ de la costa del Pacífico colombiano (Glynn et al., 1982; Muñoz y Zapata, 2013). Los corales dominantes son duros ramificados del género Pocillopora, con presencia de grandes colonias de corales masivos de los géneros Pavona y Gardineroseris en las zonas profundas (Zapata y VargasÁngel, 2003).

Durante septiembre de 2019 se capturaron cinco individuos de T. lucasanum sobre la planicie coralina del arrecife de La Azufrada, entre 10:00 y 12:00 h, empleando un trasmallo (longitud: $8 \mathrm{~m}$, altura: $1.5 \mathrm{~m}$, ojo de malla: 1,27 $\mathrm{cm} \times 1,90 \mathrm{~cm})$. En campo se realizaron varios intentos de captura empleando diferentes artes de pesca $(v . g$. arpón hawaiano, nasa de pesca manual, trasmallo); sin embargo, la agilidad y rapidez que caracteriza a estos peces dificultó su captura y resultó en un bajo tamaño de la muestra. Para cada individuo se registró la longitud total y estándar, el peso total y eviscerado (Tabla 1), y posteriormente se realizó la disección del estómago y el intestino, los cuales se preservaron en etanol al $70 \%$. En el laboratorio, todas las presas o fragmentos distinguibles fueron removidos de cada estómago (incluyendo la parte anterior del intestino) y luego fueron identificadas hasta el menor nivel taxonómico posible, contadas y pesadas en una balanza analítica (peso seco:
Species of Thalassoma are known for their trophic versatility and broad dietary preference, as well as for presenting a generalized foraging behavior in a wide spectrum of reef microhabitats (Fulton et al., 2017, Dunkley et al., 2018). Although several species of this genus are recognized for their cleaning feeding behavior (Arnal et al., 2006; Baliga and Mehta, 2014; Quimbayo et al., 2017), such behavior occurs less frequently in $T$. lucasamun in the Eastern Tropical Pacific (ETP), a region where it forages meanly on invertebrates (Quimbayo et al., 2017). Most information available for this species focuses on its reproductive patterns, abundance, and distribution (Warner, 1982; Giraldo et al., 2001), but knowledge about their feeding habits is still scarce (Foster, 1987; Robertson and Allen, 2015; Quimbayo et al., 2017). To contribute to the knowledge of the trophic ecology of T. lucasanum in the ETP, we characterized its diet by analyzing the gut contents of individuals captured in La Azufrada coral reef, Gorgona Island, Colombian Pacific.

La Azufrada is the largest (length: $780 \mathrm{~m}$, width: $80-180 \mathrm{~m}$ ) and most continuous fringing reef of the continental Gorgona Island $\left(2^{\circ} 58^{\prime} 10^{\prime \prime} \mathrm{N}\right.$ and $\left.78^{\circ} 11^{\prime} 05^{\prime \prime} \mathrm{W}\right)$, $35 \mathrm{~km}$ from the Pacific coast of Colombia (Glynn et al., 1982; Muñoz and Zapata, 2013). The dominant corals are branched stony corals of the genus Pocillopora, with large colonies of massive corals of the genera Pavona and Gardineroseris present in the deep zones (Zapata and Vargas-Ángel, 2003).

Five T. lucasanum were captured using a trammel net (length: $8 \mathrm{~m}$, height: $1.5 \mathrm{~m}$, mesh size: $1.27 \mathrm{~cm} \times 1.90 \mathrm{~cm}$ ) between 10:00-12:00 h on $\mathrm{La}$ Azufrada's reef flat throughout September 2019. Several attempts were made to capture the fish in the field using different fishing gear (v.g. Hawaiian spear, manual fishing net, trammel net); however, the agility and speed that characterize these fish made it difficult to catch them, resulting in a small sample size. Total and standard length as well as total and eviscerated weight were registered for each individual (Table 1). Then, each individual's gut was dissected and preserved in $70 \%$ ethanol. Once in the laboratory, all prey or distinguishable fragments of prey were removed of each stomach (including the anterior portion of the intestine), and identified to the lowest taxonomic level possible, counted, and weighed on an analytical balance (dry weight: $60{ }^{\circ} \mathrm{C} \times 24 \mathrm{~h}$ ) (Hyslop, 1980; Cortés, 1997; Mar-Silva et al., 2014). The digested material with no distinguishable fragments was also sorted 
$60{ }^{\circ} \mathrm{C} \times 24$ h) (Hyslop, 1980; Cortés, 1997; Mar-Silva et al., 2014). El material digerido con fragmentos no distinguibles también fue separado y pesado. Para cada ítem de presa se calculó el coeficiente de vacuidad $(\% \mathrm{~V})$, la frecuencia de ocurrencia $(\% \mathrm{~F})$, el porcentaje por número $(\% \mathrm{~N})$, el porcentaje por peso seco $(\% \mathrm{~W})$ y el índice de importancia relativa (\%RI) (George y Hadley, 1979; Hyslop, 1980; Fabi et al., 2006). Para describir la amplitud del nicho trófico se calculó el índice de Levin $\left(\mathrm{B}_{\mathrm{i}}\right)$ y su forma estandarizada $\left(\mathrm{B}_{\mathrm{A}}\right)$ (Krebs, 1999). and weighed. The vacuity coefficient $(\% \mathrm{~V})$, frequency of occurrence $(\% \mathrm{~F})$, percentage by number $(\% \mathrm{~N})$, percentage by weight $(\% \mathrm{~W})$ and the index of relative importance $(\% \mathrm{RI})$ were calculated for each prey (George and Hadley, 1979; Hyslop, 1980; Fabi et al., 2006). To describe the trophic niche breadth, Levin's index $\left(\mathrm{B}_{\mathrm{i}}\right)$ and its standardized form $\left(B_{A}\right)$ were calculated (Krebs, 1999).
Tabla 1. Resumen de medidas morfométricas de Thalassoma lucasanum recolectados para análisis de contenido estomacal. $\mathrm{n}=5$ individuos. SD: desviación estándar.
Table 1. Summary of morphometric measurements of Thalassoma lucasanum collected for gut content analysis. $\mathrm{n}=5$ individuals. SD standard deviation.

\begin{tabular}{|l|c|c|c|c|}
\hline & \multicolumn{2}{|c|}{ Longitud/Lenght $(\mathrm{mm})$} & \multicolumn{2}{c|}{ Peso/Weight (g) } \\
\hline & Total & Estándar/Standard & Total & Eviscerado/Eviscerated \\
\hline Media/Mean & 75.74 & 63.96 & 4.80 & 3.58 \\
SD & 18.66 & 16.88 & 4.21 & 3.21 \\
\hline
\end{tabular}

Se registraron 20 ítems de presas en los estómagos de T. lucasanum (V\%: 0). Debido al alto grado de digestión de la mayoría de las presas, solo un ítem fue identificado a nivel de género y cuatro a nivel de familia (Tabla 2). De las presas no identificadas, 12 fueron clasificadas en morfoespecies (un ostrácodo, dos bivalvos y nueve gasterópodos), pero debido a su pequeño tamaño, su peso individual no pudo ser cuantificado.

En La Azufrada, Thalassoma lucasanum se alimentó principalmente de pequeños invertebrados bentónicos, incluyendo moluscos, crustáceos y poliquetos (Tabla 2). Los moluscos conformaron el ítem de presa más frecuente (F\%: 100) e importante de la dieta (\%RI: 53,31). Entre los moluscos, los gasterópodos fueron las presas más frecuentes $(100 \%)$ y abundantes (50\%), seguidos por los quitones (\%F: 60) y los bivalvos (\%F: 20). Sin embargo, en términos de biomasa, la contribución de los moluscos fue baja $(\% \mathrm{~W}: 10,20)$ en comparación con los crustáceos (\%W: 39,25). Los crustáceos conformaron el segundo ítem alimentario más frecuente ( $80 \%$ e importante (\%RI: 46,69), destacándose por su frecuencia y abundancia los ostrácodos (F\%: 60, \%N: 27,63), los decápodos del género Alpheus (F\%: 20) y los copépodos (F\%: 20) (Tabla 3).

Los resultados encontrados son consistentes con las descripciones de Robertson y Allen (2015), quienes describen una dieta variada para T. lucasanum basada en
We registered 20 prey items in the gut contents of T. lucasanum (V\%: 0). Because most prey items were highly digested, only one was identified to genus level and four to family level (Table 2). From the unidentified prey, 12 were classified as morphospecies (one ostracod, two bivalves, and nine gastropods), but due to their small size, their individual weight could not be quantified.

Our results show that Thalassoma lucasanum in La Azufrada coral reef mainly feeds on small benthic invertebrates, including mollusks, crustaceans, and polychaetes (Table 2). Mollusks were the most frequent (F\%: 100) and most important prey item in the diet (\%RI: 53.31). Among mollusks, gastropods were the most frequent (100\%) and most abundant (50\%) prey, followed by chitons (\%F: 60) and bivalves (\%F: 20). However, in terms of biomass, the contribution of mollusks was low (\%W: 10.20) compared to the crustaceans consumed (\%W: 39.25). Crustaceans comprised the second most frequent (80\%) and most important (\%RI: 46.69) dietary component, with a highlighted frequency and abundance of ostracods ( $\mathrm{F} \%: 60, \% \mathrm{~N}: 27.63)$, decapods of the genus Alpheus (F\%: 20), and copepods (F\%: 20) (Table 3). 
Tabla 2. Composición de la dieta de Thalassoma lucasanum en el arrecife coralino de La Azufrada, isla Gorgona, Pacífico colombiano. Frecuencia de ocurrencia $(\% \mathrm{~F})$, porcentaje por número $(\% \mathrm{~N})$ y peso $(\% \mathrm{~W})$ e índice de importancia relativa $(\% \mathrm{RI})$ para cada presa.
Table 2. Diet composition of Thalassoma lucasanum in La Azufrada coral reef, Gorgona Island, Colombian Pacific. Frequency of occurrence $(\% \mathrm{~F})$, percentage by number $(\% \mathrm{~N})$ and weight $(\% \mathrm{~W})$, and index of relative importance $(\% \mathrm{RI})$ for each prey.

\begin{tabular}{|c|c|c|c|c|c|c|}
\hline Ítems de presas/Prey items & & & $\% \mathrm{~F}$ & $\% \mathbf{N}$ & $\% \mathrm{~W}$ & $\%$ RI \\
\hline \multicolumn{7}{|c|}{ CRUSTACEA } \\
\hline Decapoda & Alpheidae & Alpheus sp. & 20.00 & 1.32 & 37.85 & 18.59 \\
\hline Copepoda & Copepoda (n.i.) & & 20.00 & 1.32 & - & - \\
\hline \multirow{5}{*}{ Ostracoda } & Macrocyprididae & & 60.00 & 18.42 & - & - \\
\hline & Bairdiidae & & 60.00 & 7.89 & - & - \\
\hline & Ostracoda (n.i.) & & 20.00 & 1.32 & - & - \\
\hline & Total Ostracoda & & 60.00 & 27.63 & 0.70 & 22.18 \\
\hline & Partes de crustáceos/Parts of crustaceans & & 40.00 & - & 0.70 & - \\
\hline \multicolumn{7}{|c|}{ MOLLUSCA } \\
\hline Bivalvia & & & 20.00 & 2.63 & - & - \\
\hline \multirow{2}{*}{ Gastropoda } & & & 100.00 & 50.00 & - & - \\
\hline & Total Bivalvia y Gastropoda/Total of Bivalvia and Gastropoda & & 100.00 & 52.63 & 3.63 & 39.04 \\
\hline \multirow{3}{*}{ Polyplacophora } & Chitonida sp1 & & 60.00 & 5.26 & 4.89 & 17.53 \\
\hline & Chitonida sp2 & & 20.00 & 2.63 & 1.68 & 6.07 \\
\hline & Total Polyplacophora & & 60.00 & 7.89 & 6.56 & 19.58 \\
\hline POLYCHAETA & Eunicidae & & 20.00 & 1.32 & - & - \\
\hline \multicolumn{3}{|l|}{ FORAMINIFERA } & 60.00 & 7.89 & - & - \\
\hline \multicolumn{7}{|c|}{ OSTEICHTHYES } \\
\hline \multirow{2}{*}{ Partes de pez/Parts of fish } & Escamas/Scales & & 80.00 & - & - & - \\
\hline & Huesos/Bones & & 40.00 & - & - & - \\
\hline \multirow{4}{*}{ OTROS/OTHERS } & Espículas/espinas/Spicules/spines & & 40.00 & 15.79 & - & - \\
\hline & Material calcáreo/Calcareous material & & 20.00 & 1.32 & - & - \\
\hline & Material vegetal/Plant material & & 20.00 & - & 1.68 & - \\
\hline & Material digerido/Digested material & & - & - & 48.88 & - \\
\hline
\end{tabular}

moluscos, erizos, crustáceos y poliquetos. Entre estos ítems de presa, los moluscos fueron el principal recurso alimentario de T. lucasanum en La Azufrada, mientras que otros estudios han registrado a los pequeños crustáceos herbívoros como el principal componente de la dieta (Goodson, 1988; Williams, 1991). El consumo de moluscos (de cuerpo blando y/o de concha dura) se ha registrado para otras especies de Thalassoma como T. duperrey, depredador efectivo de nudibranquios (Gochfeld y Aeby, 1997), y T. lutescens, cuyos dientes faríngeos en forma molar le permiten triturar conchas y organismos de cuerpo duro como quitones (Gushima et al., 1991). Debido a la alta preferencia por los moluscos que presentó T. lucasanum en La Azufrada, la amplitud de su nicho trófico fue estrecha $\left(\mathrm{B}_{\mathrm{i}}: 1,20 ; \mathrm{B}_{\mathrm{A}}: 0,01\right)$, lo que sugirió una dieta especializada (Krebs, 1999). Sin embargo, estos resultados contrastan con
Our results are consistent with descriptions made by Robertson and Allen (2015), who documented a varied diet for T. lucasanum based on mollusks, sea urchins, crustaceans, and polychaetes. Among these prey items, mollusks were the main feeding resource of T. lucasanum in La Azufrada coral reef, while other studies have reported small herbivorous crustaceans as its main diet component (Goodson, 1988; Williams, 1991). The preference to prey upon mollusk (softbodied and/or hard-shelled) have been documented for other Thalassoma species such as T. duperrey, which is an effective predator of nudibranchs (Gochfeld and Aeby, 1997), and T. lutescens, whose molar-shaped pharyngeal teeth allow it to grind up shells and hard-bodied organisms like chitons (Gushima et al., 1991). Due to the high preference for mollusks shown by T. lucasanum in La Azufrada, its trophic niche breadth was narrow $\left(\mathrm{B}_{\mathrm{i}}: 1.20 ; \mathrm{B}_{\mathrm{A}}: 0.01\right)$, which suggest 
lo registrado para otras especies del género Thalassoma como T. bifasciatum, considerada como forrajeadora generalista que se alimenta principalmente del sustrato bentónico y que también presenta un comportamiento alimentario de limpieza facultativo (Dunkley et al., 2018). Es posible que la preferencia por moluscos encontrada en T. lucasanum en el presente estudio se deba a la alta disponibilidad de este recurso, relacionado con la gran diversidad y abundancia de moluscos que habitan los sustratos arrecifales (Robertson, 1970; Hadfield, 1976; Ramesh et al., 1996). En corales ramificados del género Pocillopora se han citado más de 100 especies de moluscos (Austin et al., 1980; Ramesh et al., 1996), lo que constituye uno de los grupos más abundantes en corales pocillopóridos, junto con los decápodos (Alvarado y Vargas-Castillo, 2012). De acuerdo con Fulton et al. (2017), la alta versatilidad trófica que caracteriza a peces del género Thalassoma podría facilitar el cambio de preferencia de sus presas hacia los recursos más comunes dentro de un hábitat dado, lo que permitiría a estas especies explotar rápidamente los recursos disponibles. Sin embargo, para determinar con mayor precisión la principal fuente de alimento de T. lucasanum y la amplitud de su nicho trófico, es necesario realizar un análisis de su dieta considerando un mayor tamaño de muestra. a specialized diet for this species (Krebs, 1999). However, these results contrast with those reported for other species of the genus Thalassoma, such as T. bifasciatum, considered as a generalist forager that feeds mainly on the benthic substrate and that also presents a facultative cleaning feeding behavior (Dunkley et al., 2018). It is possible that the preference for mollusks found in T. lucasanum in the present study is due to the high availability of this resource, related to the high diversity and abundance of mollusks that inhabit the reef substrates (Robertson, 1970; Hadfield, 1976; Ramesh et al., 1996). In branched corals of genus Pocillopora, more than 100 mollusks species have been reported (Austin et al., 1980; Ramesh et al., 1996), comprising one of the most abundant groups in pocilloporid corals, along with decapods (Alvarado and Vargas-Castillo, 2012). According to Fulton et al. (2017), the high trophic versatility that characterizes fish of the genus Thalassoma could facilitate switching their prey towards the most common resource within a given habitat, which might allow these species to rapidly exploit the available resources. However, to determine more accurately the main food sources of T. lucasanum and the breadth of its trophic niche, it is necessary to carry out an analysis of its diet considering a larger sample size.
Tabla 3. Resumen de la composición de la dieta de Thalassoma lucasanum en el arrecife coralino de La Azufrada, isla Gorgona, Pacífico Colombiano, con los principales grupos de ítems de presas registrados. Frecuencia de ocurrencia $(\% \mathrm{~F})$, porcentaje por número $(\% \mathrm{~N})$ y peso $(\% \mathrm{~W})$ e índice de importancia relativa $(\% \mathrm{RI})$ para cada presa.
Table 3. Summary of the diet composition of Thalassoma lucasanum in La Azufrada coral reef, Gorgona Island, Colombian Pacific, listing the main prey items registered. Frequency of occurrence $(\% \mathrm{~F})$, percentage by number $(\% \mathrm{~N})$ and weight $(\% \mathrm{~W})$, and index of relative importance $(\% \mathrm{RI})$ for each prey.

\begin{tabular}{|l|c|c|c|c|}
\hline Items de presas/Prey items & \%F & \%N & \%W & \%RI \\
\hline Crustacea & 80.00 & 30.26 & 39.25 & 46.69 \\
\hline Mollusca & 100.00 & 60.53 & 10.20 & 53.31 \\
\hline
\end{tabular}

La dieta de $T$. lucasamun también estuvo conformada por escamas y huesos de peces, encontrados en $80 \%$ y $40 \%$ de los estómagos analizados, respectivamente (Tabla 2). La presencia de escamas de peces puede ser resultado de las actividades de limpieza que ejercen con menor frecuencia como limpiadores facultativos (Baliga y Mehta, 2014). Cuando tienen este comportamiento, se alimentan de ectoparásitos presentes en peces, aunque esto es poco frecuente en T. lucasanum en comparación con otras especies limpiadoras (Quimbayo et al., 2017). Debido a que la mayoría de lábridos presenta una dentición que les permite explotar una amplia diversidad de presas, desde zooplancton hasta ectoparásitos de crustáceos y peces, así como bivalvos
The diet of T. lucasanum was also comprised by fish scales and bones that were found in $80 \%$ and $40 \%$ of the stomachs analyzed, respectively (Table 2). The presence of fish scales in the gut contents may result from cleaning activities performed as facultative cleaners (Baliga and Mehta, 2014). When T. lucasanum perform cleaning activities, they might feed on fish ectoparasites, although this feeding behavior is rare in T. lucasanum compared to other cleaning species (Quimbayo et al., 2017). Dentition of most wrasses allows them to exploit a wide diversity of prey, from zooplankton to ectoparasites of crustaceans and fish, as well as hard-shelled bivalves and gastropods (Westneat and Alfaro, 2005; Parenti and Randall, 2011). Therefore, it is also 
y gasterópodos de concha dura (Westneat y Alfaro, 2005; Parenti y Randall, 2011), también es posible que peces pequeños se encuentren en la dieta de T. lucasanum, aunque con menor frecuencia. Asimismo, la presencia de espinas de erizo y material calcáreo triturado sugiere que $T$. lucasanum se alimenta de erizos y podría estar ingiriendo trozos de coral durante la captura de sus presas. Un enfoque molecular para analizar el contenido estomacal podría proporcionar un análisis más robusto para la identificación de presas altamente degradadas, así como información nutricional necesaria para cuantificar con mayor precisión la importancia de cada ítem de presa para esta especie (Dunkley et al., 2018; Amundsen y Sánchez-Hernández, 2019).

En este estudio se encontró que T. lucasanum se alimenta principalmente de invertebrados bentónicos, en su mayoría moluscos de concha dura y crustáceos con estrecha asociación por el sustrato arrecifal (Figura 1). Debido al bajo possible that small fish comprise T. lucasanum diet, although less frequently. Likewise, the presence of sea urchins' spines and crushed calcareous material suggests that T. lucasanum feeds on sea urchins and could be ingesting coral pieces while capturing its prey. A molecular approach of stomach contents could provide a more robust analysis to identify highly degraded prey, as well as nutritional information necessary to quantify more accurately the importance of each prey item in this species (Dunkley et al., 2018; Amundsen and Sánchez-Hernández, 2019).

Our study shows that T. lucasanum feed mainly upon benthic invertebrates, mostly hard-shelled mollusks and crustaceans with a strong association with the coral substrate (Figure 1). Due to the small sample size, the results obtained represent an approximation to the diet for the species, contributing to establish the baseline knowledge
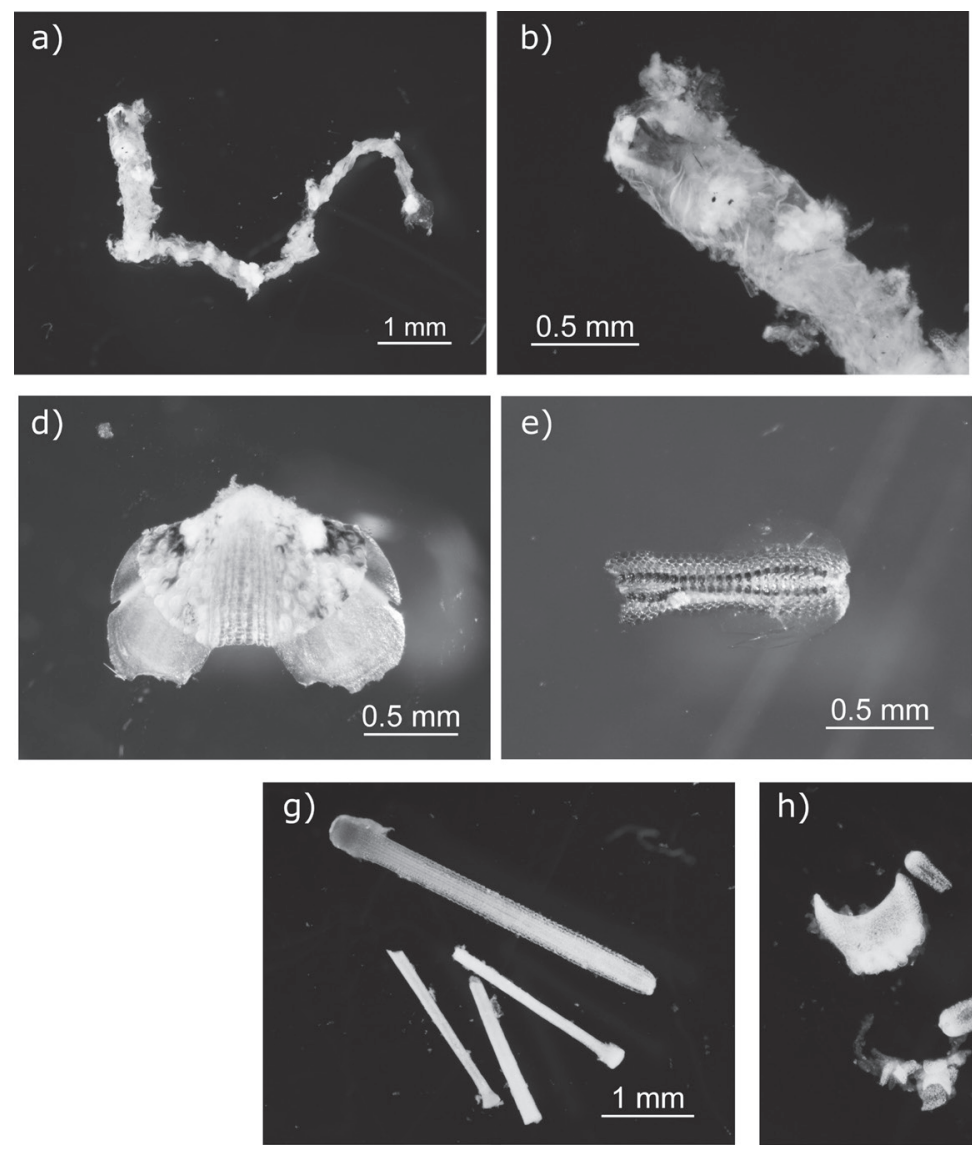

Figura 1. Ítems de presas encontrados en el contenido estomacal de Thalassoma lucasanum. Polychaeta: A) Eunicidae. B) Detalle de mandíbula de Eunicidae. Mollusca: Polyplacophora. C) Placas y tejido de Chitonida sp1 digerido. D) Detalle de placa de Chitonida sp1. E) Rádula de Chitonida sp1. F) Placas y tejido de Chitonida sp2 digerido. Otros: G) Espinas de erizo. H) Material calcáreo.

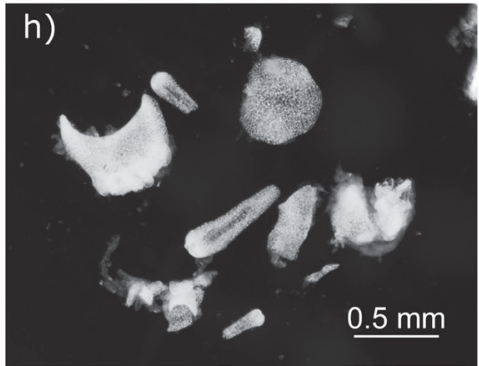

Figure 1. Prey items found in the stomach contents of Thalassoma lucasanum. Polychaeta: A) Eunicidae. B) Jaw detail of Eunicidae. Mollusca: Polyplacophora. C) Plates and tissue of digested Chitonida sp1. D) Plate detail of Chitonida sp1. E) Radula of Chitonida sp1. F) Plates and tissue of digested Chitonida sp2. Others: G) Sea urchin spines. H) Calcareous material. 
tamaño de muestra, los resultados obtenidos representan una aproximación de la dieta para la especie, lo que contribuye a establecer la línea base del conocimiento de sus hábitos alimentarios en la región. Es importante mencionar que $T$. lucasanum es una de las especies de peces más abundantes del arrecife coralino de La Azufrada (Zapata y Morales, 1997; Alzate et al., 2014; Palacios et al., 2020) y, por lo tanto, caracterizar su dieta permite entender mejor las actividades de depredación y la dinámica de las redes tróficas en los arrecifes del POT.

\section{AGRADECIMIENTOS}

Los autores agradecen a Diego Córdoba por apoyar los análisis de laboratorio, a Edgardo Londoño y Juan Felipe Lazarus por confirmar la identificación de los invertebrados, a Juan Pablo Erazo, Alejandro Perlaza, Kevin Steven Mendoza, Juan José Gallego y Olga Lucía Torres por su apoyo durante la salida de campo. Al laboratorio de imágenes de la Universidad del Valle por las tomas del contenido estomacal. Al personal de Parques Nacionales Naturales, especialmente a los funcionarios del PNN Gorgona, por el apoyo logístico brindado. Este estudio forma parte del proyecto de investigación "Estructura y función de los invertebrados crípticos móviles en dos arrecifes coralinos del Pacífico colombiano", financiado por Minciencias y la Universidad del Valle a BV, y se realizó bajo el permiso de recolección n. ${ }^{\circ} 20192000038341$. Publicación 019 del Instituto de Ciencias del Mar y Limnología (Incimar) de la Universidad del Valle. of its feeding habits in the region. Because T. lucasanum is one of the most abundant fish species in La Azufrada coral reef (Zapata and Morales, 1997; Alzate et al., 2014; Palacios et al., 2020), characterizing its diet provides a better understanding of predation activities and dynamics of food webs in coral reefs in the ETP.

\section{ACKNOWLEDGEMENTS}

The authors want to thank Diego Córdoba for his assistance in laboratory analyses, Edgardo Londoño and Juan Felipe Lazarus for confirming the identification of the invertebrates, Juan Pablo Erazo, Alejandro Perlaza, Kevin Steven Mendoza, Juan José Gallego, and Olga Lucia Torres for their help during the field trip. Many thanks to the Laboratory of Images of Universidad del Valle for taking images of the stomach contents. To the staff of Parques Nacionales Naturales, especially the staff of PNN Gorgona for their logistical support. This study is part of the research project "Estructura y función de los invertebrados crípticos móviles en dos arrecifes coralinos del Pacífico colombiano" funded by Minciencias and Universidad del Valle to $\mathrm{BV}$, and it was performed under the collection permit $\mathrm{n}$. 20192000038341. Publication 019 of the Instituto de Ciencias del Mar y Limnología (Incimar) from Universidad del Valle.

\section{BIBLIOGRAFÍA/LITERATURE CITED}

Alvarado, J.J. y R. Vargas-Castillo. 2012. Invertebrados asociados al coral constructor de arrecifes Pocillopora damicornis en Playa Blanca, bahía Culebra, Costa Rica. Rev. Biol. Trop., 60(2): 77-92. https://doi.org/10.15517/rbt.v60i2.19965

Alzate, A., F.A. Zapata, and A. Giraldo. 2014. A comparison of visual and collection-based methods for assessing community structure of coral reef fishes in the Tropical Eastern Pacific. Rev. Biol. Trop., 62: 359-371.

Amundsen, P.A. and J. Sánchez-Hernández. 2019. Feeding studies take guts - critical review and recommendations of methods for stomach contents analysis in fish. J. Fish Biol., 95: 1364-1373

Arnal, C., O. Verneau, and Y. Desdevises. 2006. Phylogenetic relationships and evolution of cleaning behaviour in the family Labridae: importance of body colour pattern. J. Evol. Biol., 19(3): 755-763. https://doi.org/10.1111/j.1420-9101.2005.01059.x

Austin, A.D., S.A. Austin, and P.F. Sale. 1980. Community structure of the fauna associated with the coral Pocillopora damicornis (L.) on the Great Barrier Reef. Mar. Freshw. Res., 31(2): 163-174. https://doi.org/10.1071/MF9800163

Baliga, V.B. and R.S. Mehta. 2014. Scaling patterns inform ontogenetic transitions away from cleaning in Thalassoma wrasses. J. Exp. Biol., 217: 35973606. https://doi.org/10.1242/jeb.107680

Cortés, E. 1997. A critical review of methods of studying fish feeding based on analysis of stomach contents: application to elasmobranch fishes. Can. J. Fish. Aquat. Sci., 54: 726-738. https://doi.org/10.1139/cjfas-54-3-726

Dunkley, K., J. Cable, and S.E. Perkins. 2018. The selective cleaning behaviour of juvenile blue-headed wrasse (Thalassoma bifasciatum) in the Caribbean. Behav. Proc., 147: 5-12. https://doi.org/10.1016/j.beproc.2017.12.005 
Fabi, G., S. Manoukian, and A. Spagnolo. 2006. Feeding behavior of three common fishes at an artificial reef in the northern Adriatic Sea. Bull. Mar. Sci., 78: 39-56.

Foster, S.A. 1987. Acquisition of a defended resource: a benefit of group foraging for the neotropical wrasse, Thalassoma lucasanum. Environ. Biol. Fishes, 19(3): 215-222. https://doi.org/https://doi.org/10.1007/BF00005350

Fulton, C.J., P.C. Wainwright, A.S. Hoey, and D.R. Bellwood. 2017. Global ecological success of Thalassoma fishes in extreme coral reef habitats. Ecol. Evol., 7: 466-472. https://doi.org/10.1002/ece3.2624

George, E. and W.F. Hadley. 1979. Food and habitat partitioning between rock bass (Ambloplites rupestris) and smallmouth bass (Micropterus dolomieui) young of the year. Trans. Am. Fish. Soc., 108: 253-261. https://doi.org/10.1577/1548-8659(1979)108<253:FAHPBR>2.0.CO;2

Giraldo, A., C. Gómez, and F. Ospina. 2001. Abundance and spatial distribution of Thalassoma lucasanum (Gill, 1863) in a coral reef of the Eastern Tropical Pacific. Bull. Mar. Sci., 68(1): 147-152.

Glynn, P.W., H. von Prahl, and F. Guhl. 1982. Coral reefs of Gorgona Island, Colombia, with special reference to corallivores and their influence on community structure and reef development. An. Inst. Invest. Mar. Punta Betín, 12: 185-214

Gochfeld, D.J. and G.S. Aeby. 1997. Control of populations of the coral-feeding nudibranch Phestilla sibogae by fish and crustacean predators. Mar. Biol., 130: 63-69. https://doi.org/10.1007/s002270050225

Goodson, G. 1988. Fishes of Pacific coast. Stanford Univ. Press, California. 267 p.

Gushima, K., Y. Hazumi, and S. Kakuta. 1991. Growth-related changes in diet and foraging behavior of the yellow wrasse Thalassoma lutescens at Kuchierabu Island. Jap. J. Ichthyol., 38(3): 307-313. https://doi.org/10.11369/jji1950.38.307

Hadfield, M.G. 1976. Molluscs associated with living tropical corals. Micronesica, 12: 133-148.

Hyslop, E.J. 1980. Stomach contents analysis—a review of methods and their application. J. Fish. Biol., 17: 411-429. https://doi.org/10.1111/j.1095-8649.1980. tb02775.x

Krebs, C. 1999. Ecological methodology. 2nd ed. Benjamin Cummings Press, California. 620 p.

Mar-Silva, V., R. Hernández y M. Medina. 2014. Métodos clásicos para el análisis del contenido estomacal en peces. Biologicas, 16:13-16.

Muñoz, C.G. y F.A. Zapata. 2013. Plan de manejo de los arrecifes coralinos del PNN Gorgona, Pacífico colombiano. Parques Nacionales Naturales y WWFColombia, Cali. 68 p.

Palacios, S., B. Valencia, and A. Giraldo. 2020. Diet of the coral hawkfish Cirrhitichthys oxycephalus (Family: Cirrhitidae) in a fringing coral reef of the Eastern Tropical Pacific. Coral Reefs, 39: 1503-1509. https://doi.org/10.1007/s00338-020-02007-4

Parenti, P. and J. Randall. 2011. Checklist of the species of the families Labridae and Scaridae: an update. Smithiana Bull., 13: $29-44$.

Quimbayo, J.P., M.S. Dias, O.R.C. Schlickmann, and T.C. Mendes. 2017. Fish cleaning interactions on a remote island in the Tropical Eastern Pacific. Mar. Biodivers., 47(2): 603-608. https://doi.org/10.1007/s12526-016-0493-2

Ramesh, D.A., R. Jeyabaskaran, and A.L.P. Pandian. 1996. Gastropods and bivalves associated with reef building corals, palk bay, southeastern India. Res. Bull. Phuket Mar. Biol. Cent., 16: 257-260.

Robertson, R. 1970. Review of the predators and parasites of stony corals, with special reference to symbiotic prosobranch gastropods. Pac. Sci., 24: 828830.

Robertson, R.D. y G.R. Allen. 2015. Peces costeros del Pacífico Oriental Tropical: sistema de información en línea. Instituto Smithsonian de Investigaciones Tropicales, Balboa, Panamá. https://biogeodb.stri.si.edu/sftep/es/thefishes/species/1675. 07/01/2020.

Warner, R. R. 1982. Mating systems, sex change and sexual demography in the rainbow wrasse, Thalassoma lucasanum. Copeia, $1982(3)$ : 653-661.

Westneat, M.W. and M.E. Alfaro. 2005. Phylogenetic relationships and evolutionary history of the reef fish family Labridae. Mol. Phylog. Evol., 36(2): 370-390. https://doi.org/10.1016/j.ympev.2005.02.001

Williams, D. 1991. Patterns and processes in the distribution of coral reef fishes. 437-474. En: Sale, P.F. (Ed.). The ecology of fishes on coral reefs. Academic Press, San Diego. 754 p.

Zapata, F.A. and Y.A. Morales. 1997. Spatial and temporal patterns of fish diversity in a coral reef at Gorgona Island, Colombia. Proc. 8th Internat. Coral Reef Symp., 1: 1029-1034.

Zapata, F.A. and B. Vargas-Ángel. 2003. Coral and coral reefs of the Pacific coast of Colombia. 419-447. En: Cortés, J. (Ed.). Latin American coral reefs. Elsevier Science B.V., Amsterdam. 508 p. 